\title{
AN INTEGRATION OF MULTICRITERIA ANALYSIS WITH GIS IN THE MALAYSIAN NATIONAL PHYSICAL PLAN
}

\author{
Nor Sallehi Kassim ${ }^{1}$ \\ National Physical Plan Division \\ FEDERAL DEPARTMENT OF TOWN AND COUNTRY PLANNING MALAYSIA \\ Rafikul Islam² \\ Department of Business Administration \\ Kulliyyah of Economics and Management Sciences \\ INTERNATIONAL ISLAMIC UNIVERSITY MALAYSIA
}

\begin{abstract}
Plan preparation process has evolved from the usage of traditional approaches of brainstorming to an advanced application of sophisticated analytical techniques coupled with powerful decision support software systems. The rationale of applying analytical techniques is to ensure that the analysis is thorough and logical and minimize the uncertainties in the decisions made. The National Physical Plan (NPP) of Malaysia is prepared on the basis of the Town and Country Planning Act 1976 (A1129). It contains a written statement that pertains to formulation of strategic policies in determining the general directions and trends of the physical development of the country. The NPP is needed to strengthen the existing national planning system so that it is more systematic, effective, and efficient. The NPP also coordinates the country's various planning agencies and authorities at the national, state and local levels and acts as the basis for preparation of lower tier physical development plans, e.g., structure and local plans. The present paper presents a case study on the NPP using a combined application of GIS and a multi-criteria decision making (MCDM) technique. While GIS has provided its capability in data storage, retrieval and analysis of data, MCDM technique has reflected its capability as the tool for aggregating the geographical data and decision maker's preferences. It is expected that the study will stimulate further applications in various planning activities in Malaysia.
\end{abstract}

Keywords: National Physical Plan (NPP), Geographic Information System (GIS), Analytic Hierarchy Process (AHP), Multiple Criteria Decision Making (MCDM)

\footnotetext{
${ }^{1}$ Mr. Nor Sallehi Kassim is currently a Senior Town Planner. He can be contacted at sallehi@townplan.gov.my

${ }^{2}$ Assoc. Professor Dr. Rafikul Islam can be contacted at rislam@iiu.edu.my
} 


\section{INTRODUCTION}

Conyers and Hill (1989) defined planning as "a continuous process, which involves decisions, or choices, about alternative ways of using available resources, with the aim of achieving particular goals at sometime in fiture". This definition involves planning with decision making, which is the process of selecting the best alternative from a number of available alternatives. Obviously, planning has goals that are to be achieved within limited resources. There are numerous types of planning. Out of these, spatial planning pertains to geographical entities, e.g., land, water, environment, etc. Over the years, spatial planning has attracted considerable attention from the researchers.

To facilitate spatial planning, researchers have developed many computer-based support systems. Perhaps the most significant one is the development of geographical information system (GIS) (Dueker and Barton, 1990; Scholten and Stillwell, 1990). Referring to GIS, Innes and Simpson (1993, p. 230) state that, "this developing technology offers an opportunity to transform and empower planning practice".

The main applications of GIS are in location choice, land suitability assessment, and collaborative decision-making (Joerin et al., 2001). Location analysis deals with the problem of selecting the most promising location for certain future activity. Saaty and Gholamnezhad (1982) have used multicriteria tool to select the most suitable location for nuclear waste disposal. Carver (1991) has addressed the same problem using GIS. For public facility planning, Yen and Hong (1996) have used GIS and location allocation modeling technique. Land suitability assessment is similar to location analysis and its goal is to map a suitability index for an entire territory of study (Hall et al., 1992; Senes and Toccolini, 1998; Joerin et al., 2001). Among the early researchers, Tinbergan (1956) and Thorbecke and Hall (1982) studied the effects of economic policies on patterns of and changes in land use. They considered the changes in land use as the result of the interaction between policy variables (e.g., infrastructure, price, etc) and exogenous parameters (e.g., resource endowment) that lead to realization of a number of goals (e.g., welfare, equity, rehabilitation). Sharifi and Rodriguez (2003) mention that land use decisions involve choices of two levels: regional and farm. They write (pp. 543-544), "at the regional level, a policy-maker is trying to decide how best to allocate resources or lead the agricultural development process in the desired direction, in the face of uncertainty about the impact of the allocation process on the other systems (economic, cultural and ecological). This uncertainty is related to the way that farmers in the economic system will respond to the new policy. At the farm level, farmers have their own decision problem: how best to respond to the new 
policy, given their own resources and objectives that are influenced by sociocultural values and impacts of the other systems. In order to reduce the uncertainty about farmer's' reactions to and support for an effective decision on a proper policy measure at the macro-level, their impact at farm level has to be evaluated". Collaborative decision support systems mainly deal with GIS and decision-making techniques (Geertman and Toppen, 1990; Jankowski et al., 2001).

The integration of multicriteria analysis (MCA) with GIS has created a powerful tool for spatial planning (Pereka and Duckstrin 1993; Jankowski, 1995). The aim of this paper is to describe how a national physical plan has been designed using GIS and multicriteria analysis tool. The details are described in the rest of the paper.

\section{NATIONAL PHYSICAL PLAN OF MALAYSIA}

The National Physical Plan of Malaysia is a significant part of the national developing planning agenda. Three levels of planning, viz., national, regional/state, and local constitute the national development plan. Figure 1 shows the relationships and various interfaces between these three types of plans. As it is clear from the figure that the ultimate objective of all the three plans is to achieve the Malaysian vision 2020 (Malaysia envisions achieving the status of a developed nation by the year 2020). The National Physical Plan (NPP) involves formulating strategic policies for the purpose of determining the general directions and trends of the physical development of the nation. The main functions of NPP are: to strengthen national plan by providing a spatial dimension to national economic policies, to coordinate various agencies and local planning activities and to provide overall policies to perform physical planning.

The Town and Country Planning Act 1976 (A1129) has stated that the Director General of Town and Country Planning Department shall upon the directive of the National Physical Planning Council prepare and submit a draft on National Physical Plan which covers Peninsular Malaysia. Once the Plan is approved, the policies of the NPP will take effect unless those are subsequently altered or replaced. In view of changing socio-economic circumstances of the country, the Act stipulates that the Plan be reviewed every five years in tandem with the review of the National Five Year Development Plan, or as and when directed by the Council. 


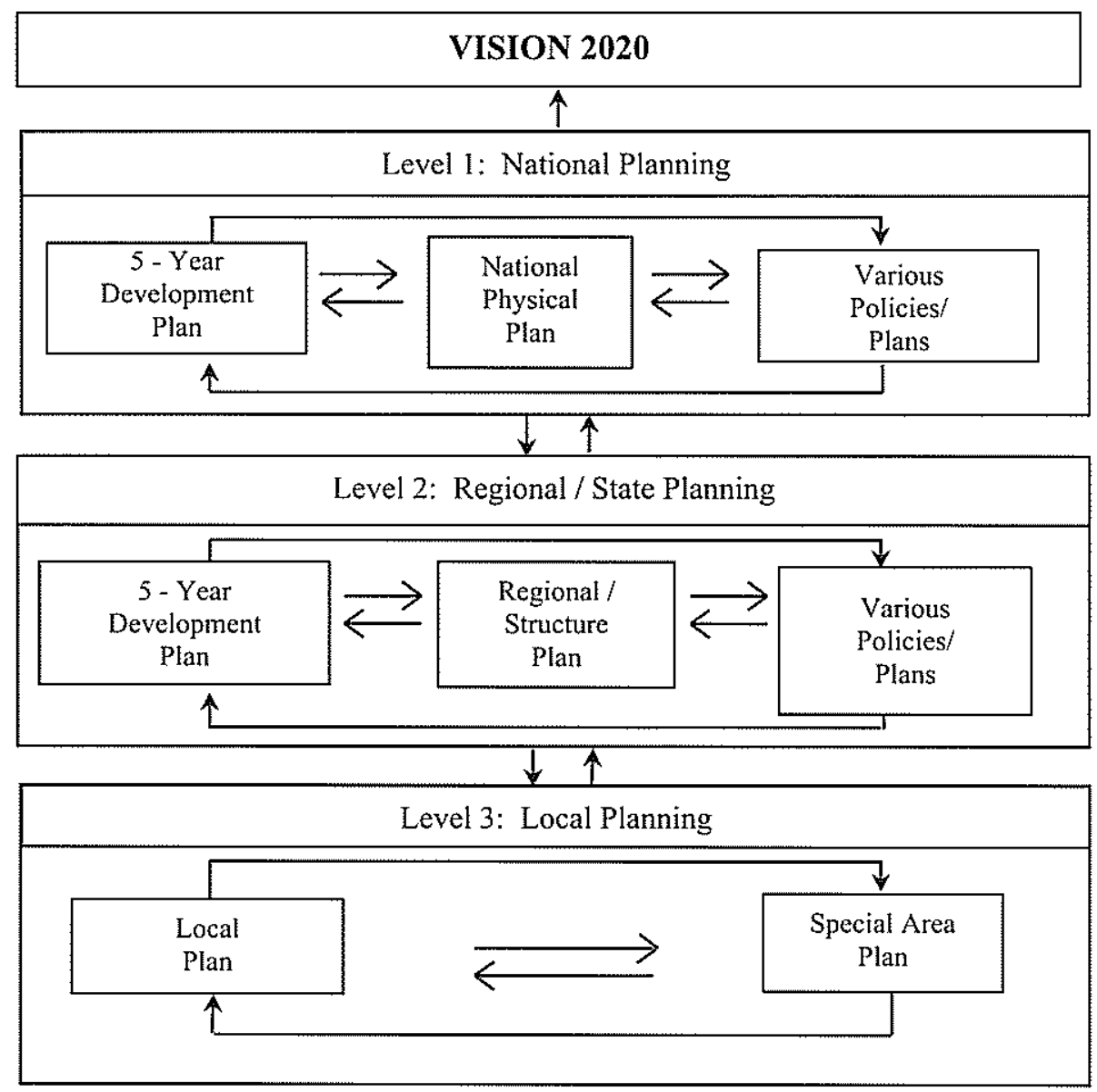

Figure 1: National development planning framework

NPP study involves seven major sectors: Global framework and Macroeconomics; Physical Planning and Urbanization; Population, Housing and Social Amenities; Infrastructure, Utilities and Transportation; Environment and Natural Resources; Information Systems; and Institutionalization and Implementation. The plan preparation process has been shown in Figure 2. The database which is developed sector wise forms the basis for NPP Information System.

The output of the NPP consists of the National Physical Framework Indicative Map and written statements that consist of policies, mechanisms for implementation, and the manual of the Planning Information System. 


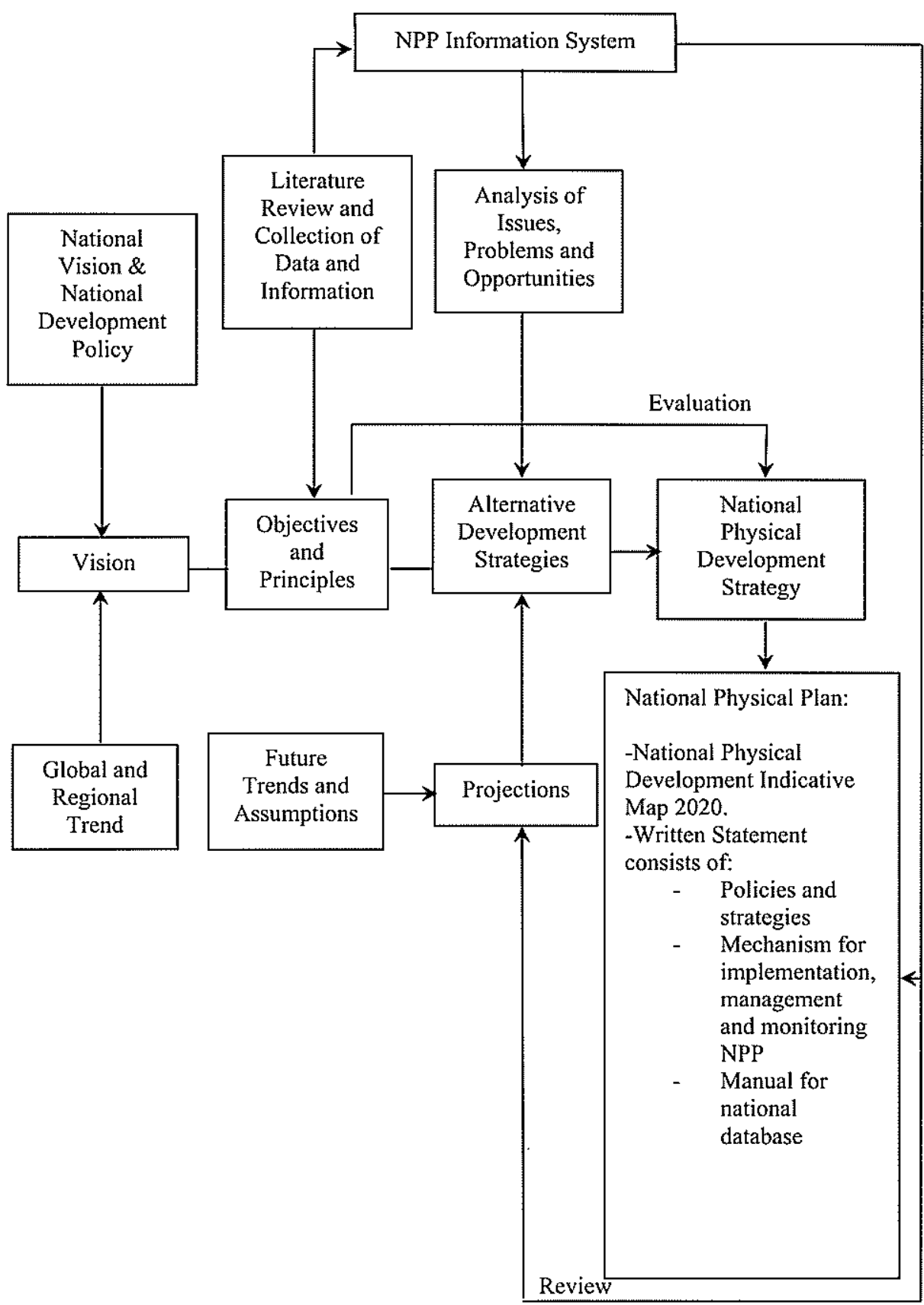

Figure 2: National physical plan preparation process 


\section{MCA AND GIS APPLICATIONS RELATED TO SPATIAL PLANNING IN MALAYSIA}

A considerable amount literature is available on the three types of spatial planning in Malaysia. At the national level, Yaakup (2001) has discussed how GIS is used for data collection, land suitability analysis and generate suitability maps. Maidin et al. (2004) have discussed the effectiveness of multicriteria analysis (MCA) to assist the generation of alternative land use development plans. Yaakup and Healey (1994) have discussed how GIS can be applied in squatter settlement planning in Kuala Lumpur. Yaakup et al. (1994) have also discussed the application of GIS for the development plan formulation and implementation at both state and district levels based on the case studies of Pahang state structure plan, Klang Valley GIS (AGISwlk) and Pekan district local plan. The above mentioned authors have also applied the MCA techniques in the formulation of strategies and policies through the generation of alternative development scenarios. However, a study on the demand of MCA and spatial planning and decision support system (SPDSS) in Malaysia by Muhammad Faris et al. (2005) have indicated the level of awareness and knowledge of MCA and SPDSS amongst professional planners were still low.

\section{NPP AND LAND SUITABILITY ANALYSIS}

The basic purpose of the present study is to identify the land in various states of Peninsular Malaysia for further urban development. Specially, the objectives are the following:

- To use multicriteria decision making (MCDM) technique and GIS to generate alternative development plans.

- To generate the preferred development plan (land suitable for development) on the basis of projected population across various states in Peninsular Malaysia.

Various stages of NPP and land suitability analysis are described below:

Stage 1: Setting up the ultimate goal: to create an efficient, equitable and sustainable national spatial framework to guide and assist in the overall development of the country towards achieving the status of a developed nation by the year 2020 .

Stage 2: Formulating the objectives: these are developed in congruence with the ultimate goal. The main objectives are the following: 
- To optimize utilization of land, infrastructure and resources

- To promote environmental quality

- To ensure equitable regional development

- To make Malaysia globally competitive

- To enhance quality of life

Stage 3: Identifying criteria and sub-criteria that are related to the objectives: the criteria and sub-criteria are shown in Table 1. Each criterion is represented by a number of sub-criteria. Details of the sub-criteria and the corresponding intensities are provided in Table 2 .

Table 1: Criteria and sub-criteria related to the objectives

\begin{tabular}{|c|c|c|}
\hline Objectives & Criteria & Sub-criteria \\
\hline $\begin{array}{l}\text { To promote } \\
\text { environmental quality }\end{array}$ & Physical Characteristics & $\begin{array}{ll}\text { - } & \text { Slope } \\
\text { = } & \text { Terrain } \\
\text { = } & \text { Soil erosion risk } \\
\text {. } & \text { Coastal erosion risk }\end{array}$ \\
\hline $\begin{array}{l}\text { To optimize utilization } \\
\text { of land, infrastructure } \\
\text { and resources }\end{array}$ & $\begin{array}{l}\text { Land, Infrastructure \& } \\
\text { Resources }\end{array}$ & $\begin{array}{ll} & \text { Water availability } \\
& \text { Accessibility to highway } \\
\text { /road } \\
\text { - } & \text { Accessibility to railway } \\
\text { - } & \text { Soil class } \\
& \text { Industrial Indices }\end{array}$ \\
\hline $\begin{array}{l}\text { To ensure equitable } \\
\text { regional development }\end{array}$ & $\begin{array}{l}\text { Social Economic } \\
\text { Development Status }\end{array}$ & $\begin{array}{l}\text { - } \quad \text { Mean household Income } \\
\text { - Incidence of poverty } \\
\text { - Per capita GDP }\end{array}$ \\
\hline $\begin{array}{l}\text { To make Malaysia } \\
\text { globally competitive }\end{array}$ & $\begin{array}{l}\text { Proximity to Town and } \\
\text { Industry }\end{array}$ & $\begin{array}{ll}\text {. } & \text { Proximity to big town } \\
\text { Proximity to industrial } \\
\text { areas }\end{array}$ \\
\hline $\begin{array}{l}\text { To enhance quality of } \\
\text { life }\end{array}$ & $\begin{array}{l}\text { Quality of life indices } \\
\text { Proximity - disperse to } \\
\text { medium town }\end{array}$ & $\begin{array}{l}\text { Quality of life indices } \\
\text { Proximity to small \& } \\
\text { medium town }\end{array}$ \\
\hline
\end{tabular}


Table 2: Sub-criteria and their corresponding intensities

\begin{tabular}{|c|c|}
\hline SUB-CRITERIA & INTENSITIES \\
\hline \multicolumn{2}{|l|}{ A. Physical Characteristics } \\
\hline a.1 Slope & $\begin{array}{l}\text { 1. } 0-12 \\
\text { 2. } 12-20 \\
\text { 3. } 20-25\end{array}$ \\
\hline a.2 Terrain & $\begin{array}{l}\text { 1. Lowland: below } 150 \text { meter } \\
\text { 2. Hilly: } 150-300 \text { meter }\end{array}$ \\
\hline a.3 Soil erosion risk & $\begin{array}{l}\text { 1. Low risk : }<10 \mathrm{t} / \mathrm{ha} / \mathrm{yr} \\
\text { 2. Moderate risk : } 10-50 \mathrm{t} / \mathrm{ha} / \mathrm{yr} \\
\text { 3. Moderately high risk }: 50-100 \mathrm{t} / \mathrm{ha} / \mathrm{yr} \\
\text { 4. High risk }: 100-150 \mathrm{t} / \mathrm{ha} / \mathrm{yr}\end{array}$ \\
\hline a.4 Coastal erosion risk & $\begin{array}{l}\text { 1. Within } 5 \mathrm{~km} \text { coastal erosion risk } \\
\text { 2. Outside } 5 \mathrm{~km} \text { coastal erosion risk }\end{array}$ \\
\hline \multicolumn{2}{|c|}{ B. Land, Infrastructure and Resources } \\
\hline $\begin{array}{l}\text { b.I Water availability within } \\
\text { catchment areas }\end{array}$ & $\begin{array}{l}\text { 1. Water sufficient until year } 2050 \\
\text { 2. Water deficient by year } 2050 \\
\text { 3. Water deficient by year } 2020\end{array}$ \\
\hline $\begin{array}{l}\text { b.2 Accessibility-distance to } \\
\text { highway interchanges and } \\
\text { road networks }\end{array}$ & $\begin{array}{l}\text { 1. } 10 \mathrm{~km} \text { buffer from the Interchange, } 5 \mathrm{~km} \text { buffer along the } \\
\text { U } 5 \text { reads, and } 3 \mathrm{~km} \text { buffer along the U } 4 \text { roads } \\
\text { 2. } 25 \mathrm{~km} \text { buffer from the Interchange, } 5-10 \mathrm{~km} \text { buffer along } \\
\text { the U5 roads, and } 3-8 \mathrm{~km} \text { buffer along the U4 roads } \\
3.33 \mathrm{~km} \text { buffer from the Interchange, } 10-15 \mathrm{~km} \text { buffer } \\
\text { along the U } 5 \text { roads, and } 8-10 \mathrm{~km} \text { buffer along the U4 } \\
\text { roads } \\
4.40 \mathrm{~km} \text { buffer from the Interchange, } 15-20 \mathrm{~km} \text { buffer } \\
\text { along the U } 5 \text { roads, and } 10-15 \mathrm{~km} \text { buffer along the U4 } \\
\text { roads }\end{array}$ \\
\hline $\begin{array}{l}\text { b. } 3 \text { Accessibility to railway } \\
\text { station }\end{array}$ & - $10 \mathrm{~km}$ buffer from railway station \\
\hline $\begin{array}{l}\text { b. } 4 \text { Industrial development } \\
\text { indices }\end{array}$ & $\begin{array}{l}\text { - Rank } 1 \\
\text { - Rank } 2 \\
\text { - Rank } 3 \\
\end{array}$ \\
\hline b.5 Soil Class & $\begin{array}{l}\text { 1. Class } 5 \\
\text { 2. Class } 4 \\
\text { 3. Class } 3 \\
\text { 4. Class } 2 \\
\text { 5. Class } 1\end{array}$ \\
\hline \multicolumn{2}{|c|}{ C. Social Economics Development status } \\
\hline c.1 Mean household income & $\begin{array}{l}\text { 1. Mean household income by state above national average } \\
\text { 2. Mean household income by state below national average }\end{array}$ \\
\hline c. 2 Per capita GDP & $\begin{array}{l}\text { 1. Per capita GDP by state above national average } \\
\text { 2. Per capita GDP by state below national average }\end{array}$ \\
\hline c. 3 Incidence of poverty & $\begin{array}{l}\text { 1. Incidence of poverty by state above national average } \\
2 \text {. Incidence of poverty by state below national average }\end{array}$ \\
\hline
\end{tabular}




\begin{tabular}{|c|c|}
\hline \multicolumn{2}{|l|}{ d.1 Proximity to Town } \\
\hline Big town $(>100,000$ population) & $\begin{array}{l}1 .<10 \mathrm{~km} \text { radius } \\
2.10-20 \mathrm{~km} \text { radius } \\
3.20-40 \mathrm{~km} \text { radius }\end{array}$ \\
\hline $\begin{array}{l}\text { Medium town }(30,001 \text { to } \\
100,000 \text { population })\end{array}$ & $\begin{array}{l}1 .<5 \mathrm{~km} \text { radius } \\
2.5-15 \mathrm{~km} \text { radius } \\
3.15-30 \mathrm{~km} \text { radius } \\
\end{array}$ \\
\hline $\begin{array}{l}\text { Small town }(10,000 \text { to } 30,000 \\
\text { population })\end{array}$ & $\begin{array}{l}1 .<5 \mathrm{~km} \text { radius } \\
2.5-10 \mathrm{~km} \text { radius } \\
3.10-20 \mathrm{~km} \text { radius } \\
\end{array}$ \\
\hline \multicolumn{2}{|l|}{ d.2 Proximity to industry areas } \\
\hline Industry 1 & 1. Within $5 \mathrm{~km}$ from industrial areas \\
\hline Industry 2 & 2. Between $5-10 \mathrm{~km}$ from industrial areas \\
\hline Industry 3 & 3. Between $10-15 \mathrm{~km}$ from industrial areas \\
\hline Industry 4 & 4. Between $15-20 \mathrm{~km}$ from industrial areas \\
\hline d.3 International airport port & $20 \mathrm{~km}$ buffer from airport and seaport. \\
\hline d.4 Local airport port & $20 \mathrm{~km}$ buffer from airport and seaport. \\
\hline \multicolumn{2}{|l|}{ E. Quality of Life } \\
\hline e.1 Quality of life index & $\begin{array}{l}\text { 1. Rank 1 } \\
\text { 2. Rank } 2 \\
\text { 3. Rank } 3 \\
\text { 4. Rank } 4 \\
\text { 5. Rank } 5\end{array}$ \\
\hline
\end{tabular}

Stage 4: Determining the weights of the criteria/sub-criteria and their intensities: the Analytic Hierarchy Process (AHP) (Saaty, 1990) has been used to determine the weights. Four consultants (names are shown in Figure 3) in four different areas (architecture, transportation engineering, civil engineering, and environment) were involved in forming the pairwise comparison matrices. Expert Choice was used to compute the weights from the matrices (see Figure 3).

Stage 5: Transferring weights to GIS: the weights generated by using AHP are transferred to GIS package. The data on various sub-criteria are already captured in NPP database. Criteria maps are prepared using the data and the weights.

Stage 6: Performing land suitability analysis: the criteria maps are aggregated (see Figure 4) to form a composite plan which shows the most suitable area for future development. Figure 5 shows the output of land suitability analysis. In the functional land suitability analysis, the suitable areas for development are matched with demand for land. 


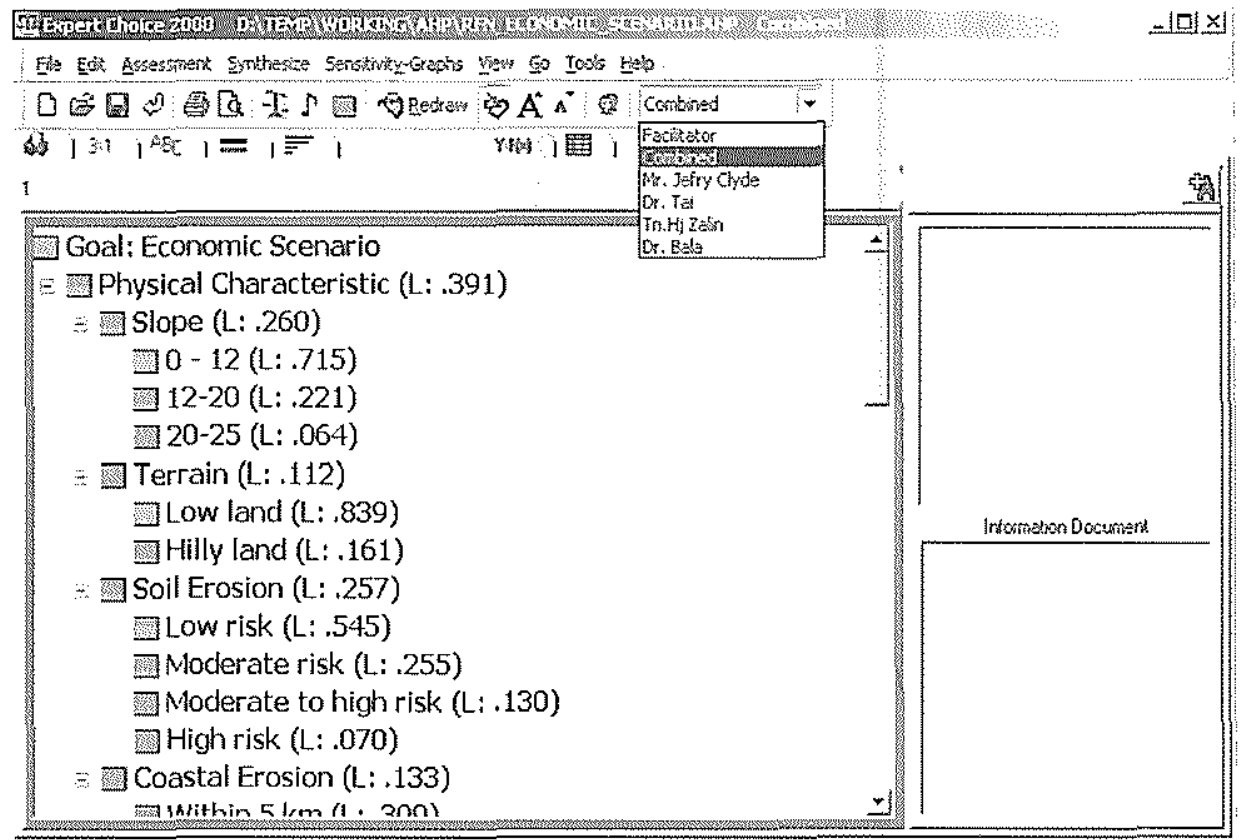

Figure 3: Assigning weights to the criteria/sub-criteria and the intensities by using the Expert Choice software.
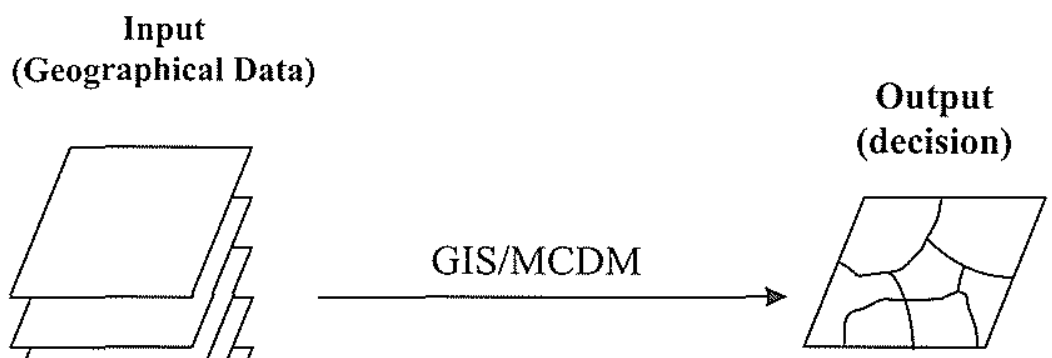

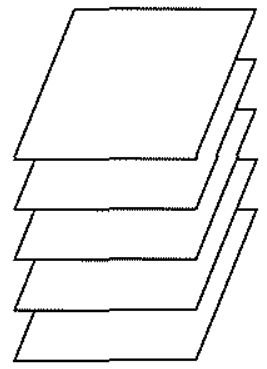

Criteria

Composite Plan

Figure 4: The way of obtaining a composite plan for NPP 


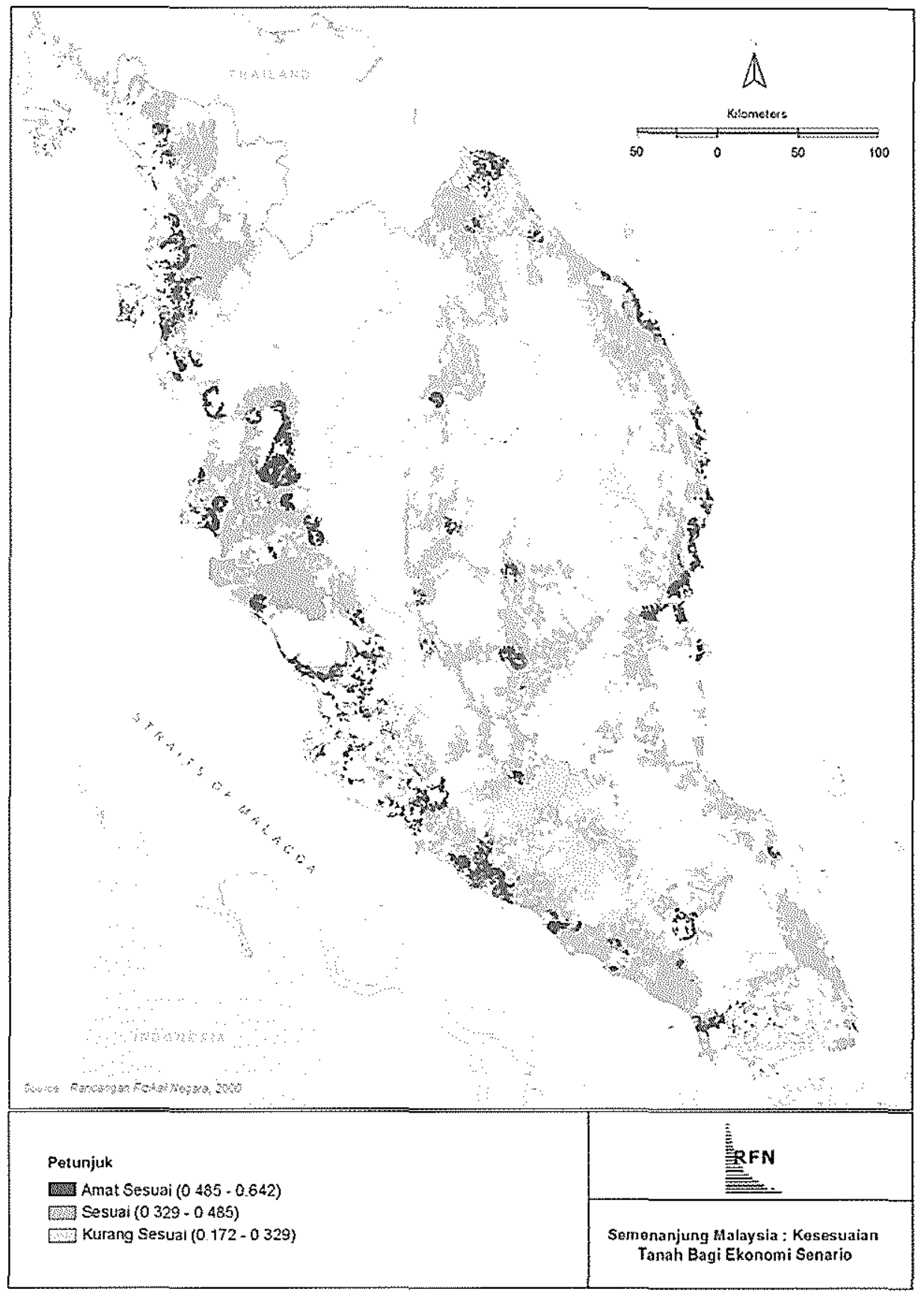

Figure 5: Land suitability diagram for peninsular Malaysia 
We have estimated the demand for land based on the population projection by the year 2020, with the assumption that 30 people stay in one hectare area. Based upon the land suitability analysis, Table 3 shows the amount of land available for urbanization.

Table 3: Urban land required and available land in peninsular Malaysia

\begin{tabular}{|c|c|c|c|}
\hline \multirow{2}{*}{ State / Region } & \multirow{2}{*}{$\begin{array}{c}\text { Urban Land } \\
\text { Required }\end{array}$} & \multicolumn{2}{|c|}{ Land Available } \\
\hline & & $\begin{array}{c}\text { Available } \\
\text { Land }\end{array}$ & $\begin{array}{c}\text { Net } \\
\text { Position }\end{array}$ \\
\hline & $\mathrm{Ha}$ & $\mathrm{Ha}$ & $\mathrm{Ha}$ \\
\hline Perlis & 1,800 & 840 & -960 \\
\hline Kedah & 28,560 & 18,152 & $-10,408$ \\
\hline Pulau Pinang & 25,080 & 20,499 & $-4,581$ \\
\hline Perak & 26,760 & 133,530 & $+106,770$ \\
\hline Northern Region & 82,200 & 173,021 & $+90,821$ \\
\hline Selangor & 111,720 & 13,884 & $-97,836$ \\
\hline W.P. Kuala Lumpur & 19,600 & 5,123 & $-14,477$ \\
\hline Negeri Sembilan & 10,040 & 22,989 & $+12,949$ \\
\hline Melaka & 10,760 & 36,397 & $+25,637$ \\
\hline Central Region & 152,120 & 78,393 & $-73,727$ \\
\hline Johor & 52,080 & 135,976 & $+83,896$ \\
\hline Southern Region & 52,080 & 135,976 & $+83,896$ \\
\hline Pahang & 17,720 & 113,000 & $+95,280$ \\
\hline Terengganu & 9,960 & 55,207 & $+45,247$ \\
\hline Kelantan & 17,440 & 18,456 & $+1,016$ \\
\hline Eastern Region & 45,120 & 186,663 & $+141,543$ \\
\hline Peninsular Malaysia & 331,520 & 574,053 & $+242,533$ \\
\hline
\end{tabular}

\section{CONCLUSIONS}

Over the years, planning problems have become more and more complicated. The complexities have been compounded due to the presence of multiple objectives, multiple criteria, multiple stakeholders, and multiple actors. Many of these criteria are conflicting and subjective in nature. The model or tool to be used in the planning process is expected to tackle these complexities, 
simultaneously giving an output plan that is viable. This paper shows how a powerful MCDM technique can facilitate the planning process with the help of GIS. It is expected that further application of the model used in the present study will be extended to similar applications including structure and local plans.

\section{REFERENCES}

Carver, S. 1991. Integrating multi-criteria evaluation with geographical information systems. International Journal of Geographical Information Systems, 5, 321-339.

Conyers, D. and Hill, P. 1989. An Introduction to Development Planning in the Third World. New York: John Wiley.

Dueker, K.J.D. and Barton, P. 1990. GIS in land development planning process: balancing the needs of land planners. Journal of the American Planning Association, 56, 483-491.

Geertman, S. and Toppen, F. 1990. Regional planning for new housing in Randstad Holland. In: Scholten, H. J. and Stillwell, J. C. H. (eds) Geographical Information Systems for Urban and Regional planning. Dordrecht: Kluwer Academic Publishers.

Hall, G.B., Wang, F. and Subakyono. 1992. Comparison of Boolean and fuzzy classification methods in land suitability analysis by using geographical information systems. Environment and Planning A, 24, 497-516.

Innes, J.E. and Simpson, D.M. 1993. Implementing GIS for planning: lessons from the history of technological innovation. APA Journal, 59, 230-236.

Jankowski, P. 1995. Integrating geographical information systems and multiple criteria decision making methods. International Journal of Geographical Information System, 9, 251-273.

Jankowski, P. Andrienko, N. and Andrienko, G. 2001. Map-centered exploratory approach to multiple criteria spatial decision making. International Journal of Geographical Information Science, 15(2), 101127.

Joerin, F., Theriault, M. and Musy, A. 2001. Using GIS and outranking multicriteria analysis for land-use suitability assessment. International Journal of Geographical Information Science, 15(2), 153-174.

Maidin, M. A., Pangga, D., and Galab, N. 2004. Pelaksanaan kaedah penilaian multi criteria penyediaan pelan pembangunan guna tanah utama di Bandar pekan dan kawasan Sekitar. Proceedings of the National Conference on GIS Towards Strengthening Planning and Urban Monitoring, $31^{\text {st }}$ March, Universiti Teknologi Malaysia. 
Muhammad Faris Abdullah, Alias Abdullah, Mansor Ibrahim and Dazilah Abdul Samad. 2005. "A Study of the Demand of Spatial Planning and Decision Support System in Malaysia" in Planning Malaysia Joumal, III, 47-60, Malaysian Institute of Planners.

Pereka, J.M.C and Duckstein, L. 1993. A multiple criteria decision making approach to GIS based land suitability evaluation. International Journal of Geographical Information System, 7, 407-424.

Saaty, T.L. 1990. The Analytic Hierarchy Process: Planning, Priority Setting, and Resource Allocation. Pittsburgh: RWS Publications.

Saaty, T.L. and Gholamnezhad, H. 1982. High level nuclear waster management: Analysis of options. Environment and Planning B, 9, 181196.

Scholten, H.J. and Stillwell, J.C.H. (eds) 1990. Geographical information systems for urban and regional planning. Dordrecht: Kluwer Academic Publishers.

Senes, G. and Toccolini, A. 1998. Sustainable land-use planning in protected rural areas in Italy. Landscape and Urban planning, 42, 107-117.

Sharifi, M.A. and Rodriguez, E. 2003. A planning support system for policy formulation in water resources rehabilitation. In: Geertman, S. and Stillwell, J. (eds) Planning Support Systems in Practice. Berlin: SpringerVerlag.

Thorbecke, E. and Hall, L. 1982. Nature and scope of agricultural sector analysis: an overview. In: E. Thorbecke (eds) Agriculture sector analysis and models in developing countries, FAD Economic and Social Development, Paper No. 5, FAD, Rome.

Tinbergen, J. 1956. Economic Policy: Principles and Decision. Amsterdam: North Holland Publishing Company.

Yaakup, A. B. 2001. Aplikasi data GIS dan hubungkaitnya dengan pelan spatial Negara. Proceedings of the GIS National Spatial Plan Workshop, 21-22 March, Port Dickson.

Yaakup, A.B. and Healey, R.G. 1994. A GIS approach to spatial modeling for squatter Settlement Planning in Kuala Lumpur. Environment and Planning B: Planning and Design, 21, 21-34.

Yaakup, A.B., Johar, F., Maidin, M.A., and Ahmad, E.F. 2004. GIS and decision support systems for Malaysian development plan studies, Proceedings of the National Conference on SPDSS, 7-8 September, International Islamic University Malaysia.

Yen, A. G. and Hong, C.M. 1996. An integrated GIS and location allocation approach to public facilities planning - an example of open space planning. Computers, Environment and Urban Systems, 20, 339-350. 